\title{
教师组织幼儿用餐活动存在的问题及对策研究
}

鞠俊欢

淮北师范大学

DOI:10.32629/er.v3i5.2740

[摘 要] 幼儿用餐活动直接影响着幼儿的生长发育,因此需要教师给予幼儿恰当可行的组织和指导。所以,幼儿教师应合理搭配、交替使用多 种活动类型; 幼儿教师应增加活动的趣味性, 实现活动效果最佳化; 幼儿教师应掌握丰富的知识, 丰富餐前介绍内容; 幼儿教师应对幼儿保持耐 心和爱心。

[关键词] 教师; 幼儿; 组织用餐; 幼儿用餐活动

幼儿用餐活动是一日生活中的较为复杂的一个步骤, 保教老师组织起 来也很困难, 因此教师的组织显得尤为重要。笔者在幼儿园实习期间, 了解 到教师们能够认识到用餐教育的重要性, 也在尽力组织好这一环节, 但总 会出现的种种问题, 比如: 保教老师随意组织活动, 教师代替幼儿取餐, 教 师催促幼儿进餐, 教师给幼儿喂饭, 强行为幼儿添加食物, 餐前介绍食物内 容单一等问题。基于此, 笔者进行实地研究, 致力于为这些问题提出科学的 解决方法, 促进幼儿的身心健康、和谐地发展。

1 教师组织幼儿用餐活动存在的问题

1. 1教师重复使用单一活动类型, 活动效果欠佳

教师在组织幼儿用餐前的准备活动时经常重复使用一种活动类型, 这 与教师的态度有关, 也与教师的组织能力有关。当前幼儿园的某些教师因 为时间短等客观因素, 不重视幼儿的餐前准备, 采取敷衍态度随意组织一 个简单的活动时间就糊弄过去了。虽然教师组织的类型很多, 但实际开展 过程中经常重复使用同一两种活动类型, 甚至是一种活动内容, 比如音乐 活动, 教师经常组织孩子们就唱那几首, 使其它活动等得不到开展。其次, 教师组织活动的活动效果欠佳, 没有一个活动是在餐前准备时间中顺利开 心的组织下来的。还有为了是幼儿安静下来, 不断地变换游戏, 开展的活动 缺少计划性和目的性, 不能抓住幼儿的眼球, 使得幼儿的参与度和配合度 很低。

1. 2 教师在组织幼儿进餐中对幼儿缺乏耐心和爱心

教师在组织幼儿进餐时经常会出现催促幼儿进餐、强行喂幼儿吃饭和 添加食物不合理行为的发生, 这样的行为会导致幼儿抵触教师, 抵触吃饭, 不利于幼儿养成良好的饮食习惯和饮食情绪。而这里教师的言语没有熏陶 幼儿的内心, 而是损害了幼儿美好的用餐时间。强制喂饭和添加食物不合 理两种行为也不同程度地影响到幼儿, 总的来说, 教师在组织幼儿进餐时 对幼儿缺乏耐心和爱心。

\section{2 科学组织幼儿用餐活动的建议}

2. 1幼儿教师应合理搭配、交替使用多种活动类型

保教老师应将多种活动类型相结合, 交叉运用, 就拿餐前的四种活 动类型来说, 教师要做到两两结合, 游戏活动和语言活动的结合是老师 们最喜欢的, 也是很新颖的一种结合方式, 教师应该经常变换活动花样。 例如教师可以把游戏活动《小手拍拍》与音乐活动《小鱼游》相结合, 这样既可以保证幼儿不抢拍、不落拍, 又让幼儿身体得到锻炼。当然教 师还要注意提升自己的语言表达水平, 运用语言和手势相结合的方式为
幼儿讲解活动内容, 这样的话在开展活动时, 活动内容简单易理解, 幼儿 也愿意参与。

2.2幼儿教师应增加活动的趣味性, 实现活动效果最佳化

教师应适当添加主题活动, 扩充教育内容, 增加活动内容的有趣性, 如 详细深入介绍饭菜营养价值, 将食物的营养价值灵活地编成儿童歌曲等, 教师要注意幼儿的用餐活动与音乐、故事、游戏等相结合, 教师可以将有 趣的语言和动作合理的加入某个活动, 开展积极、有趣、更容易让幼儿理 解接受的活动. 教师还应提高自己的随机应变能力, 例如大多数幼儿的注 意力从散步活动转移到主题墙饰的欣赏时, 教师应立刻变换活动内容, 满 足幼儿当时的需求。

2. 3幼儿教师应掌握丰富的知识, 丰富餐前介绍内容

教师应多方面丰富自己, 提高专业能力, 增加自身储备知识, 这样教师 可以对幼儿用餐活动组织开展的很顺畅。教师可以通过上网、看书、积极 参加培训和与同事交流学习等方法丰富自己的理论知识。教师掌握了丰富 的知识, 教师自然也能介绍餐前食物, 幼儿也能对食物有一个客观的认识。 教师具备了丰富的知识不但可以丰富餐前介绍, 在教学方面, 生活方面都 是有益处的。

[参考文献]

[1]王利.幼儿用餐教育中存在的问题初探 [J]. 教育实践与研 究,2010(15):19-21.

[2]岳海燕.浅议幼儿进餐教育[J].山东教育,2010:108-109.

[3] 肖莉莎. 唐山市第三幼儿园幼儿饮食行为研究 [D]. 呼和浩特: 内蒙 古师范大学,2013.

[4]孙秀英. 餐前讲述活动在幼儿教育中的价值探讨[ J]. 开封教育学院 学报,2018(03):225-226.

[5]中华人民共和国教育部.幼儿园教育指导纲要(试行)[S].2001.

[6]郑景云.幼儿园进餐活动创新的实践与探索 [J]. 幼儿教育研 究,2016(03):29-31.

[7]史艳丽.幼儿进餐环节中教师指导行为的个案研究[D]. 鞍山: 鞍山 师范学院,2017.

作者简介:

鞠俊欢(1997--),女,汉族,山东禹城人, 研究生(2019级硕士)。研究 方向：学前教育。 